Supplement of Biogeosciences, 16, 3853-3867, 2019

https://doi.org/10.5194/bg-16-3853-2019-supplement

(C) Author(s) 2019. This work is distributed under

the Creative Commons Attribution 4.0 License.

(c) (1)

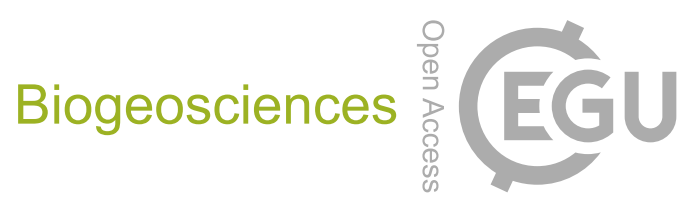

Supplement of

\title{
Modelling the response of net primary productivity of the Zambezi teak forests to climate change along a rainfall gradient in Zambia
}

\section{Justine Ngoma et al.}

Correspondence to: Justine Ngoma (justinangoma@yahoo.com)

The copyright of individual parts of the supplement might differ from the CC BY 4.0 License. 


\section{Supplementary information}

2 Table S1. Soil physical and chemical properties used for the simulations in LPJ-GUESS model

\begin{tabular}{|c|c|c|c|c|c|c|c|c|c|}
\hline Site & Horizon (cm) & 0 - 10 & $10-20$ & $20-30$ & $30-50$ & $50-100$ & $100-120$ & $120-150$ & Average value \\
\hline \multirow{8}{*}{ Sesheke } & Nitrogen (\%) & 0.02 & 0.03 & 0.03 & 0.03 & 0.03 & 0.03 & 0.03 & 0.03 \\
\hline & Clay (\%) & 0.43 & 0.43 & 0.43 & 0.60 & 0.60 & 0.60 & 0.60 & 0.53 \\
\hline & Silt (\%) & 0.46 & 0.49 & 0.46 & 0.60 & 0.60 & 0.60 & 0.60 & 0.54 \\
\hline & Fine sand $(\%)$ & 36.07 & 36.15 & 36.74 & 35.20 & 36.40 & 35.50 & 32.50 & 35.51 \\
\hline & Course sand $(\%)$ & 63.04 & 62.94 & 62.37 & 63.60 & 62.40 & 63.30 & 66.30 & 63.42 \\
\hline & $\mathrm{pH}-\mathrm{H} 2 \mathrm{O}$ & 5.60 & 5.60 & 5.60 & 5.61 & 5.43 & 5.43 & 5.60 & 5.55 \\
\hline & Organic carbon $(\%)$ & 0.75 & 0.68 & 0.64 & 1.16 & 0.78 & 0.67 & 0.74 & 0.77 \\
\hline & Bulky density (g/m3) & 1.46 & 1.50 & 1.55 & 1.57 & 1.60 & 1.56 & 1.56 & 1.54 \\
\hline \multirow{8}{*}{ Namwala } & Nitrogen (\%) & 0.03 & 0.03 & 0.03 & 0.04 & 0.03 & 0.03 & 0.03 & 0.03 \\
\hline & Clay $(\%)$ & 0.60 & 0.56 & 0.60 & 0.60 & 0.51 & 0.51 & 0.51 & 0.56 \\
\hline & Silt (\%) & 0.34 & 0.46 & 0.53 & 0.69 & 0.69 & 0.60 & 0.57 & 0.55 \\
\hline & Fine sand (\%) & 59.81 & 62.77 & 62.81 & 63.74 & 61.77 & 63.96 & 67.67 & 63.22 \\
\hline & Course sand $(\%)$ & 39.26 & 36.21 & 36.11 & 35.11 & 37.03 & 34.94 & 31.24 & 35.70 \\
\hline & $\mathrm{pH}-\mathrm{H} 2 \mathrm{O}$ & 5.76 & 5.77 & 5.72 & 5.67 & 5.69 & 5.74 & 5.80 & 5.74 \\
\hline & Organic carbon (\%) & 0.98 & 0.60 & 0.86 & 0.83 & 0.53 & 0.71 & 0.60 & 0.73 \\
\hline & Bulky density (g/m3) & 1.53 & 1.58 & 1.53 & 1.52 & 1.51 & 1.53 & 1.50 & 1.53 \\
\hline \multirow{8}{*}{ Kabompo } & Nitrogen (\%) & 0.04 & 0.04 & 0.04 & 0.04 & 0.04 & 0.04 & 0.03 & 0.04 \\
\hline & Clay (\%) & 0.29 & 0.41 & 0.36 & 0.26 & 0.09 & 0.09 & 0.17 & 0.31 \\
\hline & Silt (\%) & 0.60 & 0.47 & 0.63 & 0.37 & 0.60 & 0.71 & 0.63 & $\overline{0.43}$ \\
\hline & Fine sand $(\%)$ & 25.57 & 24.74 & 26.41 & 25.87 & 23.99 & 27.36 & 26.56 & 24.89 \\
\hline & Course sand (\%) & 73.54 & 74.36 & $\overline{72.60}$ & 73.50 & 75.33 & 71.84 & 72.73 & 74.31 \\
\hline & $\mathrm{pH}-\mathrm{H} 2 \mathrm{O}$ & 5.88 & 6.02 & 5.96 & 5.80 & 5.91 & 5.84 & 5.63 & 5.86 \\
\hline & Organic carbon (\%) & 1.13 & 1.10 & 1.01 & 1.06 & 0.66 & 0.58 & 0.76 & 0.90 \\
\hline & Bulky density (g/m3) & 1.56 & 1.65 & 1.70 & 2.00 & 1.98 & 2.09 & 2.12 & 1.87 \\
\hline
\end{tabular}


6 Table S2. Resolutions of all Global Circulation Models (GCMs) and characteristics of RCP 4.5 and RCP 8.5

\begin{tabular}{|c|c|c|c|c|c|}
\hline \multicolumn{6}{|c|}{ Global Circulation Models (GCMs) resolution } \\
\hline Model & CNRM-CM5.1 & EC-Earth & HADGEM2-ES & IPSL-CM5A-LR & \begin{tabular}{|l} 
MPI-ESM-LR \\
\end{tabular} \\
\hline Development Centre & CNRM-GAME \& CERFACS & ECMWF & Met Office Hadley & ICMC & MPI \\
\hline Horizontal resolution & $\mathrm{T} 127 \sim 1.4^{\circ} \sim 155 \mathrm{~km}$ & $\mathrm{~T} 159 \sim 1.125^{\circ} \sim 125 \mathrm{~km}$ & $1.25^{\circ} \times 1.875^{\circ} \sim 139 \mathrm{~km} \times 208 \mathrm{~km}$ & $1.9^{\circ} \times 3.75^{\circ} \sim 211 \mathrm{~km} \times 416 \mathrm{~km}$ & $\mathrm{~T} 63 \sim 1.9^{\circ} \sim 211 \mathrm{~km}$ \\
\hline Vertical resolution & L31 & L62 & L38 & L39 & \begin{tabular}{|l|} 
L47 \\
\end{tabular} \\
\hline References & (Voldoire et al., 2013) & (Hazeleger et al., 2011) & (Collins et al., 2011) & (Dufresne et al., 2013) & $\begin{array}{l}\text { (Giorgetta et al., 2016; } \\
\text { Jungclaus et al., 2013) }\end{array}$ \\
\hline \multicolumn{6}{|c|}{ Representative Concentration Pathways (RCPs) } \\
\hline RCP & \multicolumn{2}{|l|}{ RCP 8.5 } & \multicolumn{3}{|l|}{ RCP 4.5 } \\
\hline Radiative forcing & \multicolumn{2}{|l|}{$>8.5 \mathrm{~W} / \mathrm{m}^{2}$ in 2100} & \multicolumn{3}{|c|}{$\sim 4.5 \mathrm{~W} / \mathrm{m}^{2}$ at stabilization by 2100} \\
\hline Concentration (ppm) & \multicolumn{2}{|l|}{$>1370 \mathrm{CO}_{2}$-equiv. in 2100} & \multicolumn{3}{|c|}{$\sim 650 \mathrm{CO}_{2}$-equiv. (at stabilization after 2100 ) } \\
\hline Pathway & \multicolumn{2}{|l|}{\begin{tabular}{|l|} 
Rising \\
\end{tabular}} & \multicolumn{3}{|l|}{ Stabilization without overshoot } \\
\hline Characteristics & \multicolumn{2}{|c|}{$\begin{array}{l}\text { Lower rate of technology development, heavy reliance on fossil } \\
\text { fuels, high energy intensity, and increased use of croplands and } \\
\text { grassland driven by an increase in population }\end{array}$} & \multicolumn{3}{|c|}{$\begin{array}{l}\text { Lower energy intensity, strong reforestation programmes, decreasing use of croplands } \\
\text { and grasslands due to y ield increases and dietary changes, strong climate policies and } \\
\text { stable methane emissions. CO2 emissions increase only slightly before decline } \\
\text { commences around } 2040 \text {. }\end{array}$} \\
\hline Reference & \multicolumn{2}{|c|}{ (Moss et al., 2010; Riahi et al., 2011; Vuuren et al., 2011) } & \multicolumn{3}{|c|}{ (Moss et al., 2010; Riahi et al., 2011; Vuuren et al., 2011) } \\
\hline \multicolumn{6}{|c|}{ Me aning of acronyms: } \\
\hline \multicolumn{6}{|c|}{ CNRM-CM5.1 - Centre National de Recherches Météorologiques -Circulation Model version 5} \\
\hline \multicolumn{6}{|c|}{ EC-EARTH - European Centre Earth model } \\
\hline \multicolumn{6}{|c|}{ HADGEM2-ES - Hadley Global Environment Model 2 - Earth System } \\
\hline \multicolumn{6}{|c|}{ IPSL-CM5A-LR - Institute Pierre Simon Laplace - Circulation Model 5A- Running on low resolution grid } \\
\hline \multicolumn{6}{|c|}{ MPI-ESM-LR - Max-Planck-Institut für Meteorologie - Earth System Models - Running on low resolution grid } \\
\hline \multicolumn{6}{|c|}{ ECMWF - European Centre for Medium-Range Weather Forecasts } \\
\hline \multicolumn{6}{|c|}{ MPI - Max-Planck-Institut für Meteorologie } \\
\hline \multicolumn{6}{|c|}{ ICMC - Institut Pierre Simon Laplace Climate Modelling Centre } \\
\hline \multicolumn{6}{|c|}{$\begin{array}{l}\text { CNRM-GAME \& CERFACS - Centre National de Recherches Météorologiques - Groupe d'étude de l'Atmosphère Météorologique and Centre Européen de Recherche et de Formation } \\
\text { Avancée }\end{array}$} \\
\hline \multicolumn{6}{|c|}{$\mathrm{T}-$ Triangular truncation (horizontally) at wave numbers 127,159 , and 63 for the respective models } \\
\hline
\end{tabular}



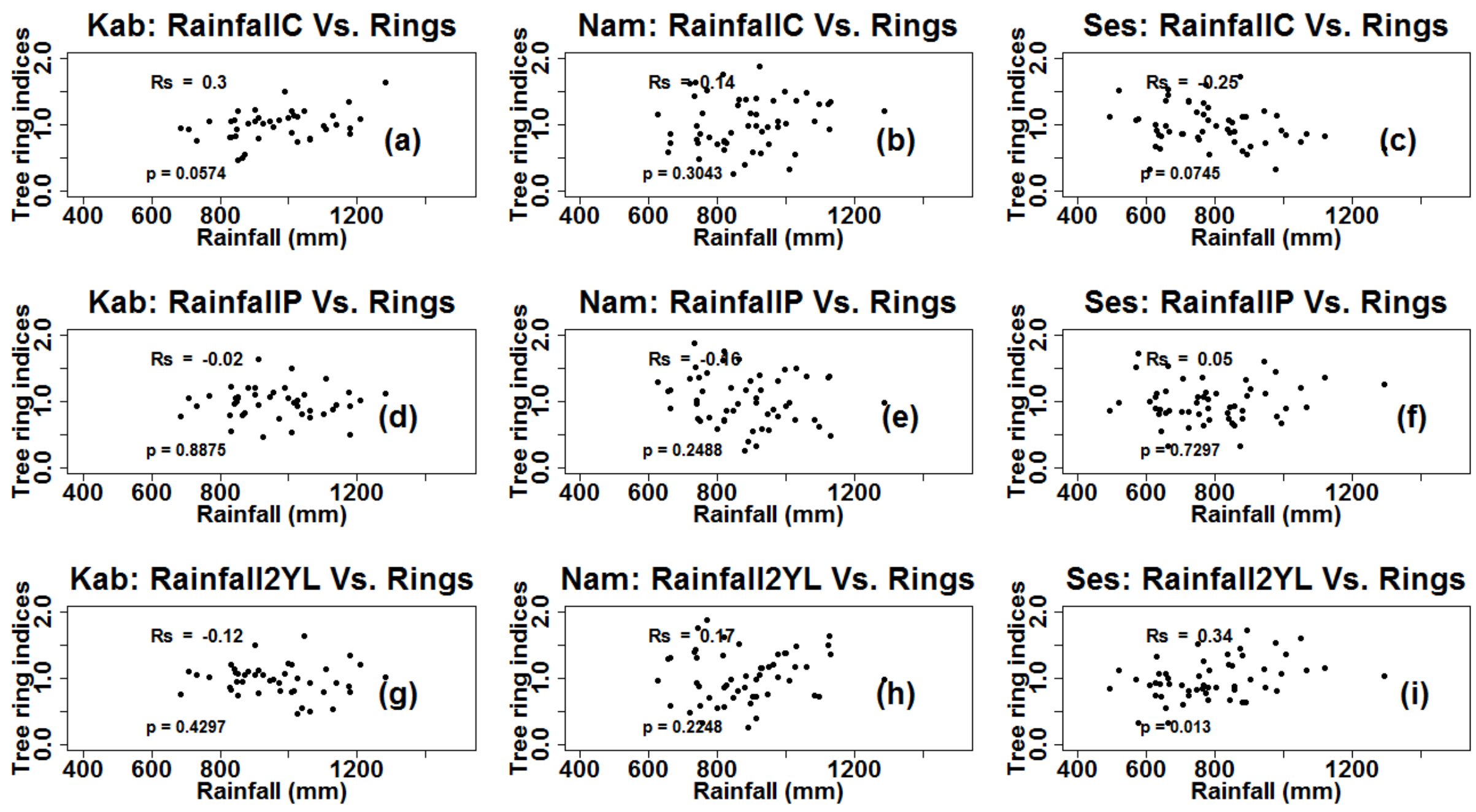

Figure S1. Spearman's correlations (Rs) between tree-ring indices and observed local total annual rainfall of the current year (a, b, and c), previous year (d, e, and f), and of the previous two years (g, h, and i) at Kabompo, Namwala and Sesheke. Kab stands for Kabompo, Nam denotes Namwala, and Ses means Sesheke. C denotes current year rainfall, $\mathrm{P}$ is previous year rainfall, and $2 \mathrm{YL}$ stands for the rainfall of previous two years. 

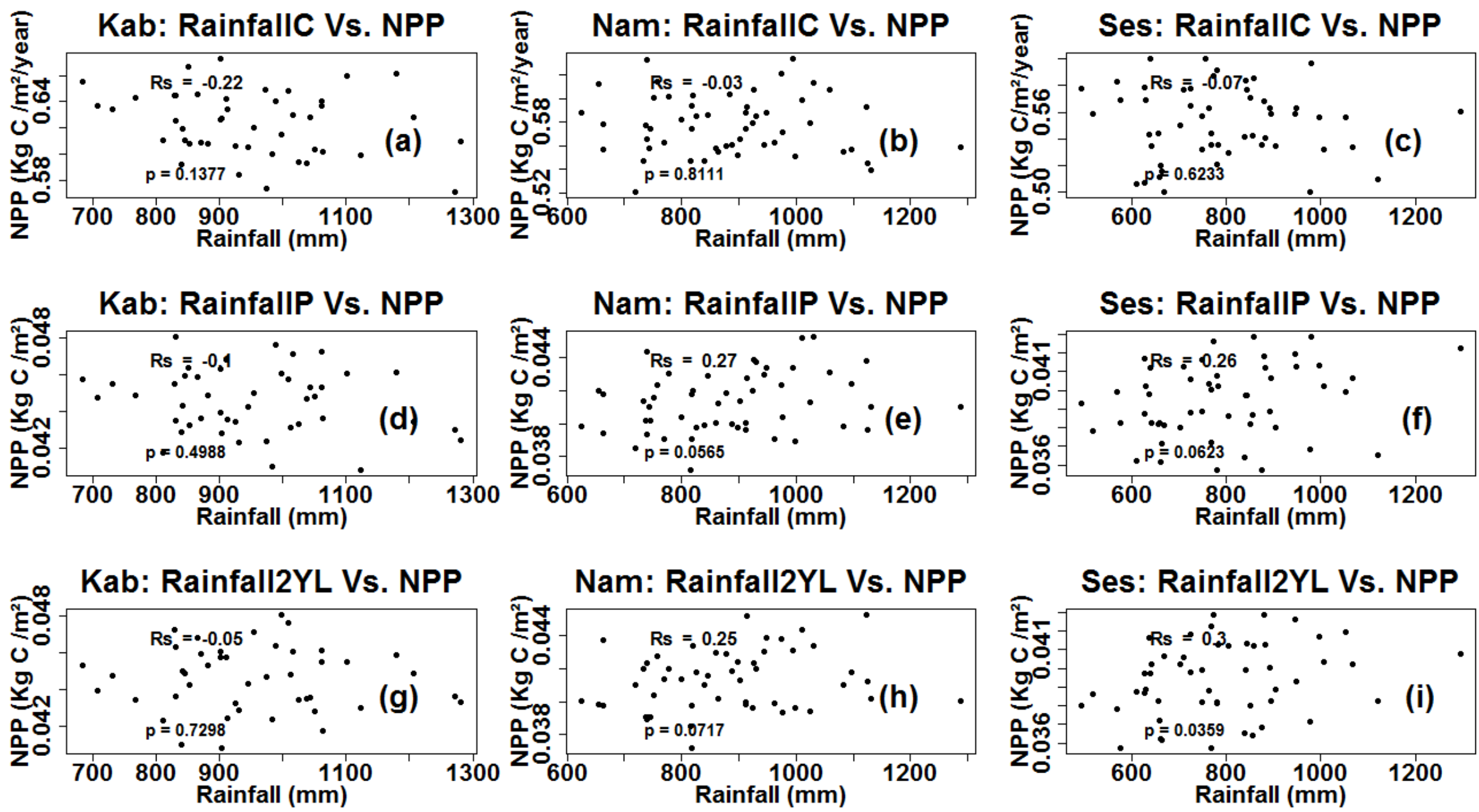

Figure S2. Spearman's correlations (Rs) between NPP and observed local total annual rainfall of the current year (a, b, and c), previous year (d, e, and f), and of the previous two years (g, h, and i) at Kabompo, Namwala and Sesheke. Kab stands for Kabompo, Nam denotes Namwala, and Ses means Sesheke. C denotes current year rainfall, P is previous year rainfall, and $2 \mathrm{YL}$ stands for the rainfall of previous two years. 

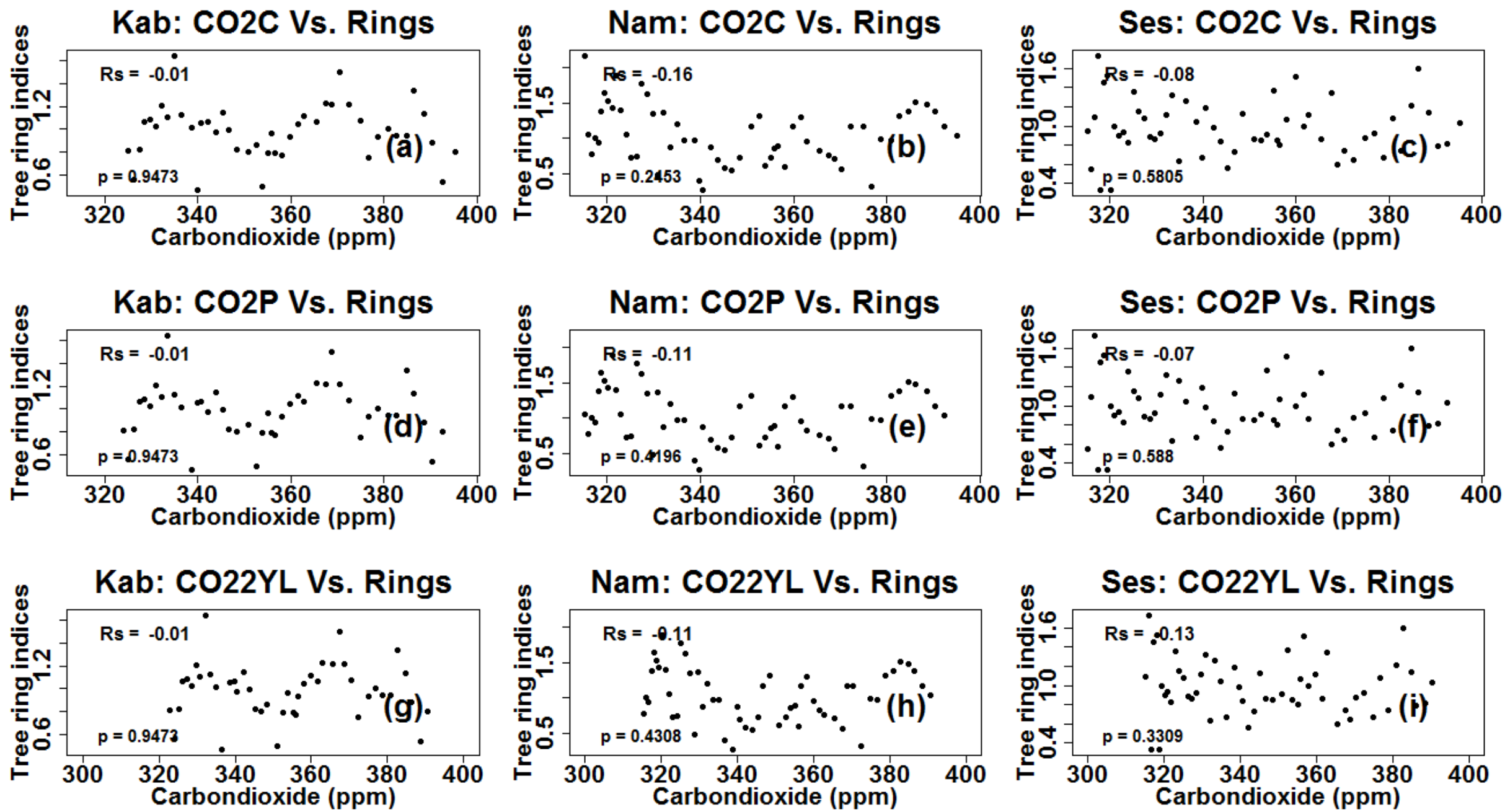

Figure S3. Spearman's correlations (Rs) between tree-ring indices and carbon dioxide $\left(\mathrm{CO}_{2}\right)$ of the current year (a, b, and c), previous year (d, e, and f), and of the previous two years (g, h, and i) at Kabompo, Namwala and Sesheke. Kab stands for Kabompo, Nam denotes Namwala, and Ses means Sesheke. $\mathrm{C}$ denotes current year CO ${ }_{2}$, P is previous year $\mathrm{CO}_{2}$, and $2 \mathrm{YL}$ stands for the $\mathrm{CO}_{2}$ of previous two years. 

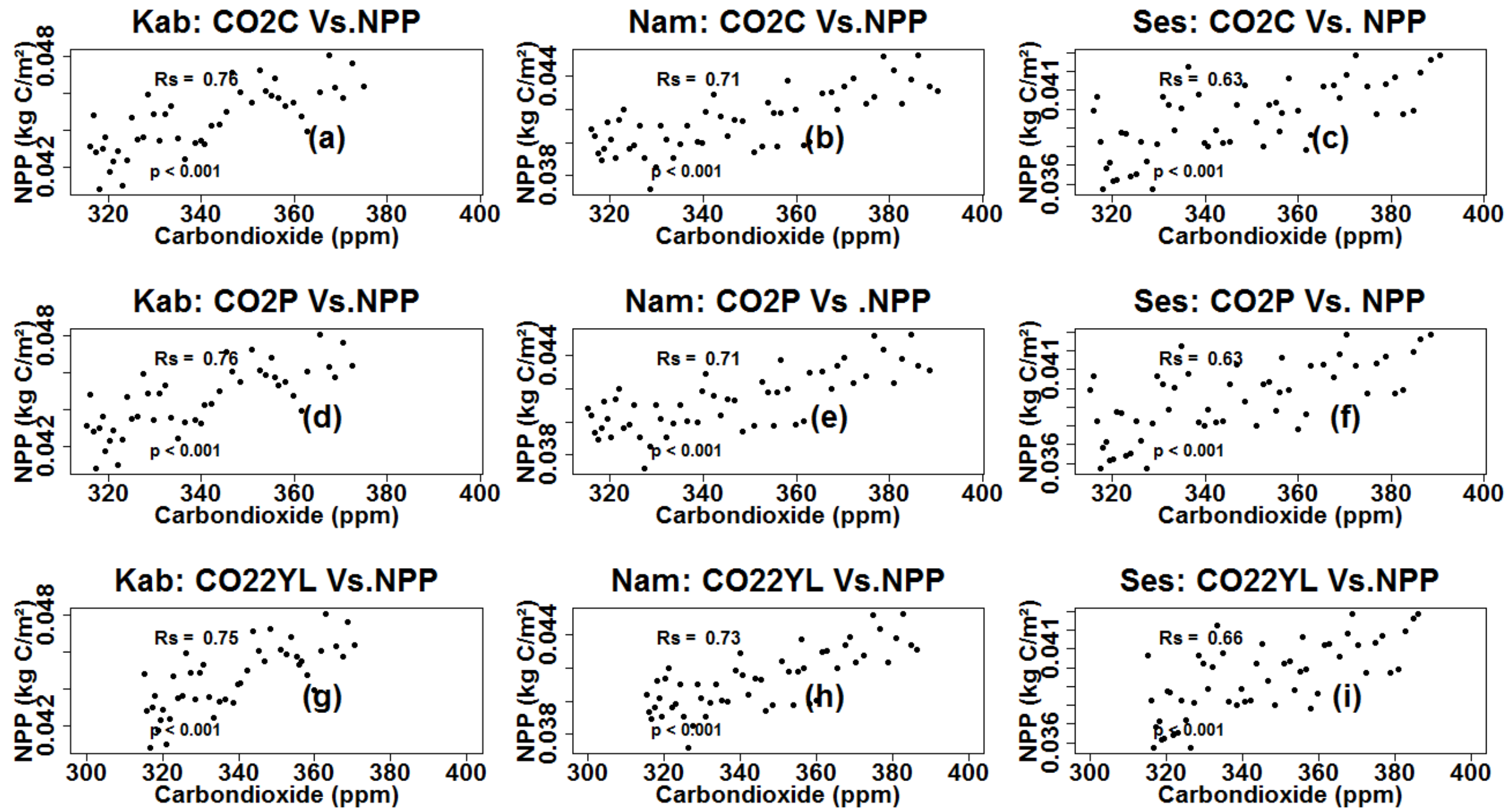

Figure S4. Spearman's correlations (Rs) between NPP and carbon dioxide $\left(\mathrm{CO}_{2}\right)$ of the current year (a, b, and c), previous year (d, e, and f), and of the previous two years (g, h, and i) at Kabompo, Namwala and Sesheke. Kab stands for Kabompo, Nam denotes Namwala, and Ses means Sesheke. $\mathrm{C}_{\text {denotes }}$ current year $\mathrm{CO}_{2}$, $\mathrm{P}$ is previous year $\mathrm{CO}_{2}$, and $2 \mathrm{YL}$ stands for the $\mathrm{CO}_{2}$ of previous two years. 

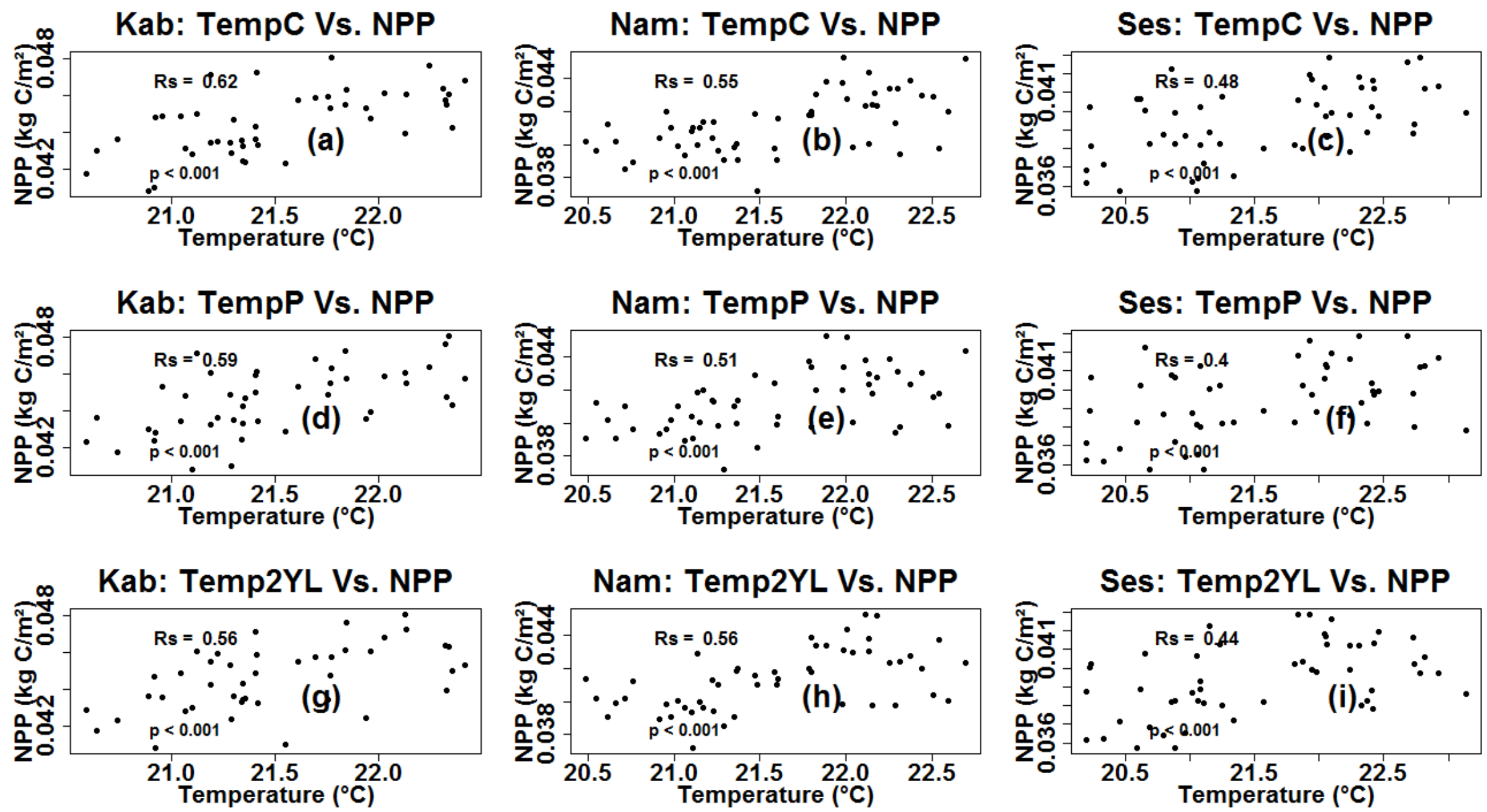

Figure S5. Spearman's correlations (Rs) between NPP and observed local mean annualtemperature of the current year (a, b, and c), previous year (d, e, and f), and of the previous two years (g, h, and i) at Kabompo, Namwala and Sesheke. Kab stands for Kabompo, Nam denotes Namwala, Ses means Ses heke, and Temp stands for temperature. $\mathrm{C}$ denotes current year temperature, $\mathrm{P}$ is previous year temperature, and $2 \mathrm{YL}$ stands for the temperature of previous two years. 


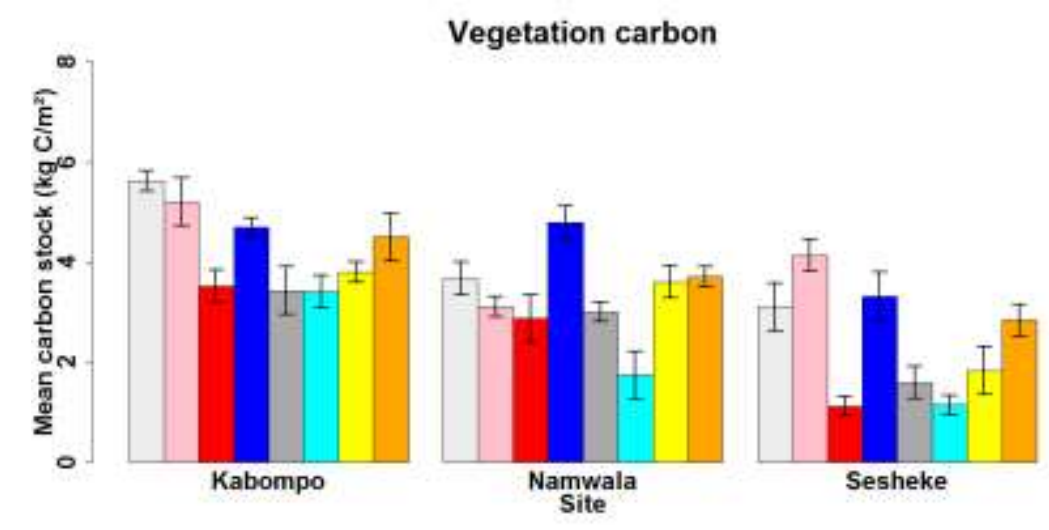

Net Primary Productivity

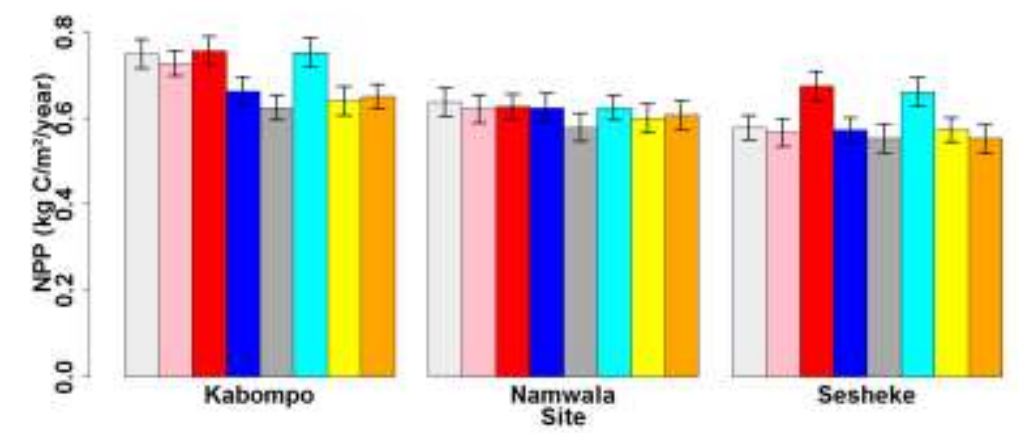

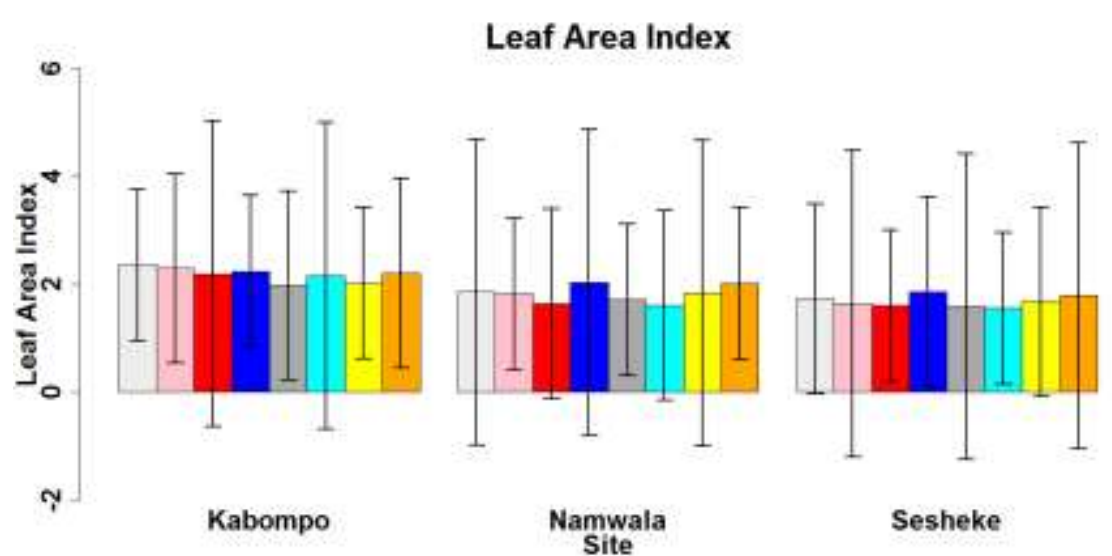

38

Simulated with default tree, default soil, and modelled climate 39

Simulated with default tree, local soil and Modelled climate

- Simulated with local tree, default soil, and modelled climate

- Simulated with default tree, default soil, and local climate

- Simulated with local tree, local soil, and local climate

= Simulated with local tree, local soil, and modelled climate

simulated with local tree, default soil, and local climate

= Simulated with default tree, local soil, and localclimate

Figure S6. Mean annual vegetation carbon stocks, LAI and NPP simulated with local and default soil and tree parameter values, and forcing the model with local and modelled climate data. Simulations were done for the period 1959-2003 


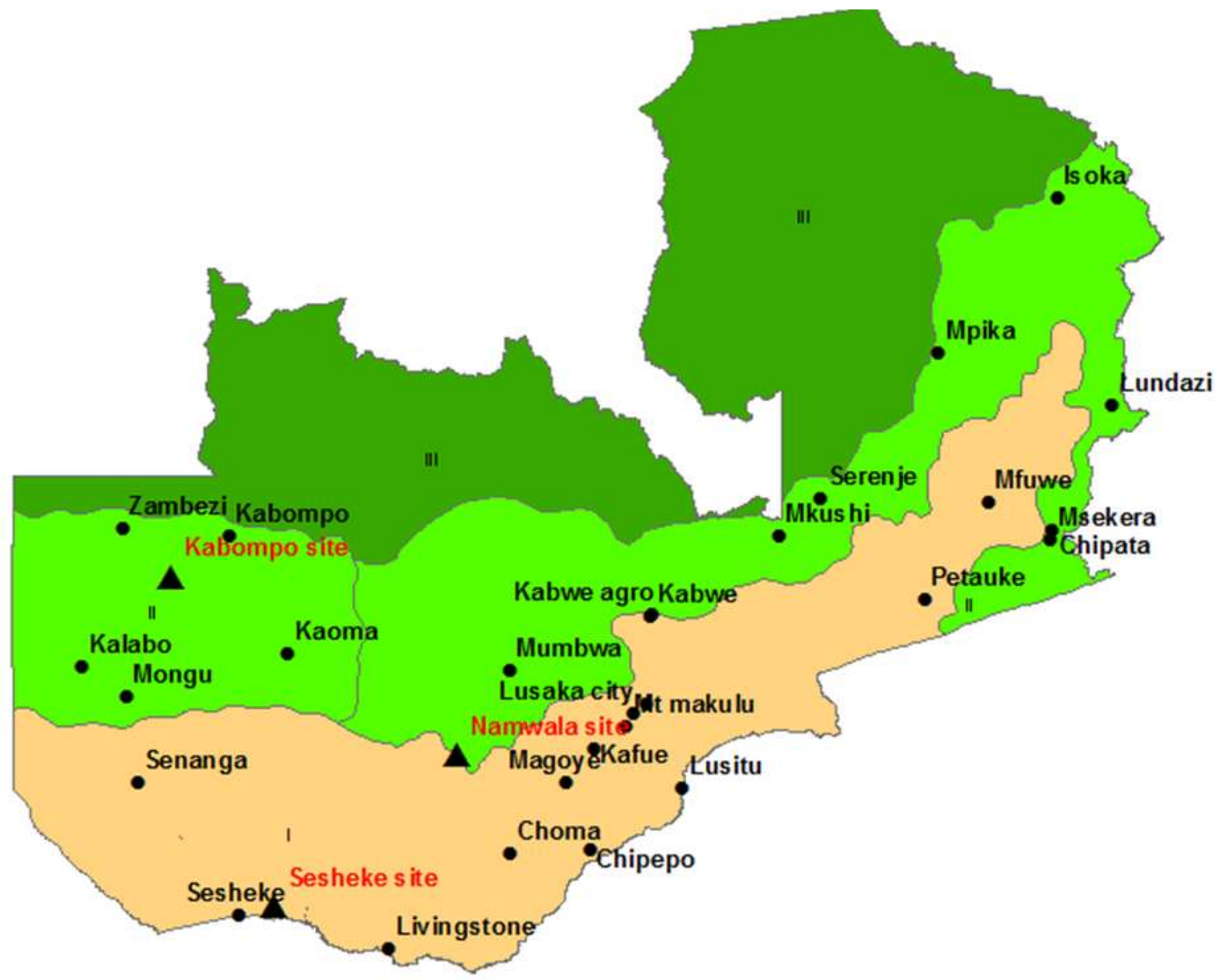

\section{Legend}

Figure S7. Study sites, weather stations and distribution of rainfall in the three ecological zones (I, II, and III). This map only shows weather stations in the two ecological zones (I and II) where we conducted ourstudies. These are the weather stations that supplied local climate data. 


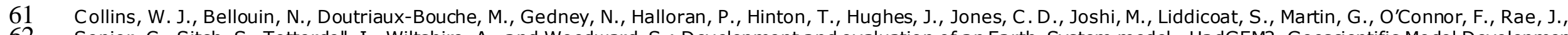

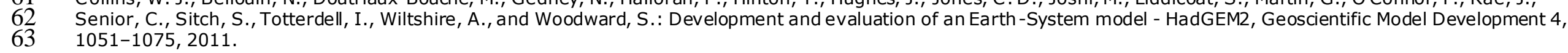

64 Dufresne, J.-L., Foujols, M.-A., Denvil, S., Caubel, A., Marti, O., Aumont, O., Balkanski, Y., Bekki, S., Bellenger, H., Benshila, R., Bony, S., Bopp, L., Braconnot, P.,

65 Brockmann, P., Cadule, P., Cheruy, F., Codron, F., Cozic, A., Cugnet, D., de Noblet, N., Duvel, J.-P., Ethé, C., Fairhead, L., Fichefet, T., Flavoni, S., Friedlingstein, P.,

66 Grandpeix, J.-Y., Guez, L., Guilyardi, E., Hauglustaine, D., Hourdin, F., Idelkadi, A., Ghattas, J., Joussaume, S., Kageyama, M., Krinner, G., Labetoulle, S., Lahellec, A.

67 Lefebvre, M.-P., Lefevre, F., Levy, C., Li, Z. X., Lloyd, J., Lott, F., Madec, G., Mancip, M., Marchand, M., Masson, S., Meurdesoif, Y., Mignot, J., Musat, I., Parouty, S.,

68 Polcher, J., Rio, C., Schulz, M., Swingedouw, D., Szopa, S., Talandier, C., Terray, P., Viovy, N., and Vuichard, N.: Climate change projections using the IPSL-CM5 Earth

69 System Model: from CMIP3 to CMIP5, Climate Dynamics, 40, 2123-2165, 2013.

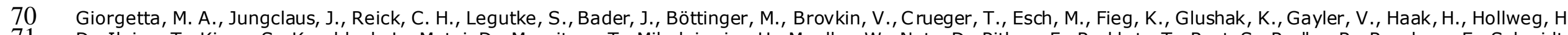

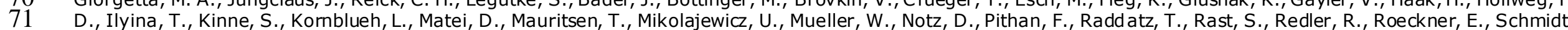

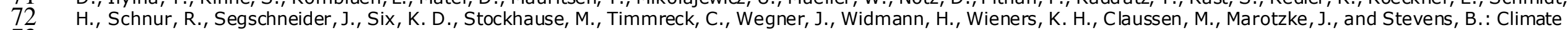
and carbon cycle changes from 1850 to 2100 in MPI-ESM simulations for the Coupled Model Intercomparison Project phase 5, J. Adv. Model. Earth Syst., 5, $572-597,2016$.

Hazeleger, W., Wang, X., Severijns, C., tefa nescu, S. S., Bintanja, R., Sterl, A., Wyser, K., Semmler, T., Yang, S., Van den Hurk, B., Van Noije, T., Van der Linden, E., and Van der Wiel, K.: EC-Earth V2.2: description and validation of a new seamless earth system prediction model, Climate Dynamics, doi: 10.1007/s00382-011-1228-5, 2011. 2011.

Jungclaus, J. H., Fischer, N., Haak, H., Lohmann, K., Marotzke, J., Matei, D., Mikolajewicz, U., Notz, D., and Storch, J. S.: Characteristics of the ocean simulations in the Max Planck Institute Ocean Model (MPIOM) the ocean component of the MPI-Earth system model, J. Adv. Model. Earth Syst., 5, 422-446, 2013.

Moss, R. H., Edmonds, J. A., Hibbard, K. A., Manning, M. R., Rose, S. K., van Vuuren, D. P., Carter, T. R., Emori, S., Kainuma, M., Kram, T., Meehl, G. A., Mitchell, J. F., Nakicenovic, N., Riahi, K., Smith, S. J., Stouffer, R. J., Thomson, A. M., Weyant, J. P., and Wilbanks, T. J.: The next generation of scenarios for climate change research and assessment, Nature, 463, 747-756, 2010.

Riahi, K., Rao, S., Krey, V., Cho, C., Chirkov, V., Fischer, G., Kindermann, G., Nakicenovic, N., and Rafaj, P.: RCP 8.5-A scenario of comparatively high greenhouse gas emissions, Climatic Change, 109, 33-57, 2011.

Voldoire, A., Sanchez-Gomez, E., Salas y Mélia, D., Decharme, B., Cassou, C., Sénési, S., Valcke, S., Beau, I., Alias, A., Chevallier, M., Déqué, M., Deshayes, J., Douville, H., Fernandez, E., Madec, G., Maisonnave, E., Moine, M.-P., Planton, S., Saint-Martin, D., Szopa, S., Tyteca, S., Alkama, R., Belamari, S., Braun, A., Coquart, L., and Chauvin, F.: The CNRM-CM5.1 global climate model: description and basic evaluation, Climate Dynamics, 40, $2091-2121,2013$.

Vuuren, D. P., Edmonds, J., Kainuma, M., Riahi, K., Thomson, A., Hibbard, K., Hurtt, G. C., Kram, T., Krey, V., Lamarque, J. -F., Masui, T., Meinshausen, M., Nakicenovic, N., Smith, S. J., and Rose, S. K.: The representative concentration pathways: an overview, Climatic Change, 109, 5-31, 2011. 